\title{
Tax Reform as an Instrument for the Stability of the National Economy
}

\author{
Ján Dobrovič ${ }^{1, *}$, Yaroslava Kostiuk $^{1,2}$, Petra Plachtová ${ }^{1}$ \\ ${ }^{1}$ Institute of Technology and Business in České Budějovice, Faculty of Corporate Strategy, Okružní 517/10, 37001 České Budějovice, \\ Czech Republic \\ ${ }^{2}$ University of Zilina, Faculty of Operation and Economics of Transport and Communications, Univerzitna 1, 01026 Zilina, Slovakia
}

\begin{abstract}
This article presents the results of the survey on the needs and expectations of people affected by the tax reform so that to assess the tax reform in Slovak Republic along with the overall satisfaction with the tax \& customs system and also to identify deficiencies in the area of tax and customs administration. We have started from the existing functional organizational structures and tax administration systems not only in Slovakia, but also in Hungary, Poland, Czech Republic and Slovenia, while the basic prerequisite for the study was to increase the efficiency of the tax system as a whole. Based on the trend analysis, we assume that the tax and customs reform will make a significant contribution to increasing the system efficiency and, ultimately, to a more positive perception of taxes.
\end{abstract}

Keywords: taxes; tax reform; trend analyses; efficiency; Slovakia

\section{Introduction}

Tax administration in Slovakia is governed by the principles established after 1989. Despite the efforts made in recent years to reduce the number of employees, the system of financial administration in Slovakia can be considered inefficient in terms of increasing the competitiveness of the state. The general tendency of the present is to complain about inflexible, reluctant bureaucratic apparatus, which, on the one hand, leads to the reluctance of citizens to meet the tax liabilities and, on the other, state measures are getting only stricter [1]. This situation ultimately leads to the aforementioned reduction in competitiveness of the state and reduction of its credibility in the eyes of own [2].

The aim of this contribution is to overview the financial management system in Slovakia, to find critical points that affect this unfavorable situation described above and to propose an optimal solution (in the context of the European Union). Slovakia's financial management needs to be seen in a wider context here. We thus stem from the existing functional organizational structures and tax administration systems not only in Slovakia, but also in Hungary, Poland, Czech Republic and Slovenia, assuming the need to change of the organizational structure, its optimization as well as the introduction of marketing principles in the field of customer orientation to achieve a positive image of tax administration in the eyes of the public. For this purpose, we conducted a survey, the results of which reflect the assessment of the current situation. We anticipate that the tax and customs reform will make a significant contribution to increasing the efficiency of the system and, ultimately, to the positive perception of taxes, perceived today as socially unpopular obligations [1,3].

Slovakia is the eighth most attractive European country in terms of tax systems according to the survey conducted by KPMG International. Its results reflect the views of more than 400 tax specialists in international companies operating in Europe. The evaluation criteria were: attractiveness, administrative difficulty, consistency, long-term stability, the scope of legislation, rates and relations with tax authorities. According to the survey results, at European level, the least attractive area is the scope of tax legislation. The ranking of the states was determined on the basis of absolute attractiveness, which was calculated as the difference in percentage of the respondents, according to which the key aspects of their domestic tax systems were attractive, and the percentage of dissatisfied respondents [1]. In this KPMG chart, which was based on the survey of European business representatives' views on the attractiveness of domestic tax regimes, the best position was reached by Cyprus, followed by Ireland and Switzerland. Positive assessments of these three countries can be explained by the uniform interpretation of tax legislation, minimum changes in tax laws and relatively low tax rates [4].

\footnotetext{
* Corresponding author: 24574@mail.vstecb.cz
} 


\section{Methodology}

\subsection{Tax and Tax system}

Profit reveals the efficiency of a company as well as the positive and negative aspects of its operations [5, 6]. Under International Financial Reporting Standards, profit and profitability are often used to evaluate the performance of companies and to determine changes in economic resources [7]. In contrast, Taxes are the most important non-credit public income. There are many comprehensible definitions, but we will mention those that describe taxes from two different perspectives. From a formal legal point of view, the taxes can be understood as mandatory, statutory payments that are paid by the taxpayer of the state at the specified amount and within the specified time limits to the relevant public budget. Such a definition is related to the features of tax laws and the constitution, but for the purposes of economic tax theory it is not sufficient. That is why it should be broadened by economic considerations. From the economic-financial point of view, the tax represents the fiscal relationship between the taxpayer and the state that is used by the government to set its goals [8]. From this point of view, taxes are financial relations, characterized by non-refundability and unilateralism. But at the same time, these statements suggest the need to define taxes also in terms of philosophy, which will create a space for the examination of qualitative features [9].

Musgrave [10] classifies taxes as following: taxes levied on the goods market and taxes levied on the (production) factors market. For example, on the (production) factors market it is the payroll tax paid by the employer and on the goods market, it is a value added tax or excise tax [11]. The current business environment for SMEs is very demanding and the enterprises are less able to gain access to external resources [12]. Bilan [13] points to the interconnection of the whole system, while referring to the so-called butterfly effect which means that a small change at one place may lead to large changes in the other place.

Taxes and tax laws (more or less) directly relate to each person and his/her finances. They determine when, to whom and for what we have to pay tax, they also determine what is tax-exempt respectively not taxed. Their continuous development is evidence that the tax system cannot be closed in any country. A good tax system should bring the state treasury sufficient revenues, it should not be an administrative burden and must be sufficiently transparent. Its role is to spread the tax burden homogeneously. An optimal tax system puts emphasis on two aspects: justice and efficiency.

The main task in creating the tax system is to create a system that would allow to collect enough funds needed to fulfill the essential functions of the state and the regions, while leaving sufficient financial resources to economic entities for their life and development. The importance of taxes lies mainly in the fact that they represent the main source of state revenues. They represented the most important component of the public budget system - state budget together with tax revenues is generally considered to be an important tool for government and state policy, i.e., an instrument used by the government to implement its economic goals and tasks [1]. Current time places high demands on managers and other employees, forcing them to think about how best to optimize processes [14], not excluding the tax area.

The tax system corresponds to the economic and political organization of the state - its government and, last but not least, to the currently governing political stream [15]. Slovakia is in a stage of development when it seeks to reach the economic level of the European Union countries by creating an attractive business environment [16]. In addition, a good business environment creates a favorable environment for the development of small and medium-sized enterprises (SMEs), which are important part of the national economic system [17]. In the context of the above-mentioned Zubal'ová [18] notes that it is not possible to remove all distortions from all areas burdened with taxes, i.e. to achieve the "ideal state". If we consider the absence of an "ideal state" in the interests of optimizing the tax system, we must strive to maximize the social function of benefit and to find a balance between efficiency and justice.

Another important element that can play a role in simplification of the tax system is electronization. For example, Belas and Demjan [19] examining bank cutsomers' satisfaction found that the most significant factors of customer satisfaction are the availability of banking products and services through electronic banking. The "Doing Business 2016" which evaluates the business environment in national economies showed that Slovakia was in 29th place in a better position than the Czech Republic (36th place), which Belás and Sopková [20, p.147] consider to be the result "the simplification of the business establishment in the country and the introduction of an electronic system of filing tax declarations and the process of paying taxes itself".

\section{Results and Discussion}

In accordance with above-mentioned philosophical-theoretical starting points, we examined the effectiveness feedback of the tax administration of the Slovak Republic. The reform of the tax administration of the Slovak Republic presupposes the acceleration of the management and decision-making processes and the improvement of the transfer of information, including the feedback within the individual tax offices (TOs). Removal of one administrative management interlink will cause that eight tax offices will be managed as executive organizational units of the tax administration. From the perspective of Tax Directorate of the Slovak Republic (TD SR) this form is considerably simpler and more flexible than managing the current number of 102 tax offices through 8 offices acting as administrative centers. Similarly, the 
management of approximately 8 branches of the tax office (BTO) in the self-governing region assumes lesser requirements concerning directors of eight TOs. The advantage is also the saving on staffing, especially by decreasing the number of managers in Offices of the Tax Directorate of the Slovak Republic (OTD SR) according to the current organizational structure of OTD SR. By creating a smaller number of BTOs with increased number of employees, the transition of some of them from small TOs to TOs/BTOs will ensure the size "unification" of the individual TOs/BTOs with the parallel impact on creating the same organizational structure of all TOs/BTOs. This will allow the application of the same procedures and management system, as well as performance comparison (benchmarking), which (due to the differences in organizational structures) have so far not been possible to compare. In these intentions and on the basis of these assumptions, we have examined the acceptance of the reform by taxpayers, which we consider to be extremely important for its flawless functioning.

The presented research can be methodically classified as "face to face" category. In order to get as much relevant data as possible to identify the need, acceptance or rejection of the reform a simple questionnaire was distributed. The following criteria are considered to be relevant:

- Willingness of the tax office employees

- Competence of the tax office employees

- Tax collection - process/method and simplicity

- Collection of tariffs/customs - process/method and simplicity

- Collection of levies - process/method and simplicity

- Administrative difficulty of the tax and customs agenda

- Time saving

- Availability

- Electronicisation/computerisation - great user comfort

- Transaction costs

- Postage costs

- Labour costs

Selected key criteria were generated according to the expected benefit of the reform (if implemented). This is a qualitative and quantitative research based on the facts of the reform (mentioned in the introductory part of the contribution). The aim of the survey is to identify the needs and expectations of the people most affected by the reform. In addition, our research will spontaneously reveal the need for reform, its (in)effectiveness, through the method of generating criteria. The analysis of individual segments is based on own experience and the perception of the benefits of tax and customs reform from the citizen's point of view. Through a weighted average, we will define a qualitative mark for individual reform factors and and then we quantify them given the number of relevant answers received (i.e. completed questionnaires).

- Time horizon of the survey: 25/01/19 - 15/12/20

- $\quad$ Representative sample: 1500

- Number of questionnaires issued: 3500

- $\quad$ Number of (completed) questionnaires collected: 2187

For the purpose of the survey, respondents were divided into four age-related categories (intervals), with the following age categories being represented: 18-25 years: 384 respondents, 26-35 years: 369 respondents, 36-45 years: 359 respondents, and 46-60 years 388 respondents. The average number of respondents in the four (age) categories is 375 respondents. Calculated standard deviation is of value of 13.44. In terms of employment, the composition of respondents participating in the research in the following categories was as follows: officials: 373 respondents, entrepreneurs: 383 respondents, students: 360 respondents, not mentioned (unspecified) job: 384 respondents. Questionnaire survey was carried out in four districts, the number of respondents in each category is as follows: Prešov: 374 respondents, Bratislavacity: 385 respondents, Košice: 389 respondents, Banská Bystrica: 352 respondents. From the above qualitative analysis, it can be concluded that the different categories of respondents in terms of age, gender, employment and geographical distribution are homogeneous with minimum variations in the number of groups in each group.

To analyze the questionnaire (evaluation) questions, factor analysis was chosen as the most appropriate method for processing the given data type. Factor analysis is a multidimensional statistical method that focuses on generating new variables and aims to reduce the amount of data (data reduction) with minimal loss of information. It is based on the assumption that the dependence between the observed variables is due to the effect of a smaller number of non-measurable 
variables in the background, which are referred to as common factors. These common factors are defined as a linear combination of original variables.

The main objective of factor analysis is to know and use the structure of common factors that are considered to be the hidden (underlying) causes of mutually correlated variables, concurrently to explain and elucidate the observed dependencies in the best and most simple way. Thus, in the final solution, each variable should be correlated with a minimum number of factors, an at the same time the number of factors should be as small as possible. To assess the suitability of factor analysis as a tool, a Kaiser-Mayer-Olkin (KMO) test and Bartlett's test of sphericity was conducted (Table 1).

Table 1. KMO test, Bartlett's test

\begin{tabular}{|l|c|c|}
\hline \multicolumn{2}{|c|}{ Kaiser-Meyer-Olkin Measure of Sampling Adequacy. } & .895 \\
\hline \multirow{2}{*}{ Bartlett's Test of Sphericity } & Approx. Chi-Square & 91.564 \\
\cline { 2 - 3 } & $\mathrm{df}$ & 66 \\
\cline { 2 - 3 } & Sig. & .001 \\
\hline
\end{tabular}

Source: Authors.

Table 2. Table of eigenvalues

\begin{tabular}{|c|c|c|c|c|}
\hline \multirow{2}{*}{ Value } & \multicolumn{3}{|c|}{ Eigenvalues - Extraction: Principal components } \\
\cline { 2 - 5 } & Eigenvalue & $\begin{array}{c}\text { \% Total } \\
\text { variance }\end{array}$ & $\begin{array}{c}\text { Cumulative } \\
\text { Eigenvalue }\end{array}$ & $\begin{array}{c}\text { Cumulative } \\
\%\end{array}$ \\
\hline 1 & 1,185683 & 9,880695 & 1,185683 & 9,88070 \\
\hline 2 & 1,129148 & 9,409563 & 2,314831 & 19,29026 \\
\hline 3 & 1,073402 & 8,945018 & 3,388233 & 28,23528 \\
\hline 4 & 1,054944 & 8,791202 & 4,443177 & 37,02648 \\
\hline 5 & 1,035592 & 8,629930 & 5,478769 & 45,65641 \\
\hline 6 & 1,026562 & 8,554679 & 6,505330 & 54,21109 \\
\hline
\end{tabular}

Source: Authors.

Table 3. Table of factor loadings

\begin{tabular}{|l|c|c|c|c|c|c|}
\hline \multirow{2}{*}{} & \multicolumn{7}{|c|}{ Factor Loadings (Varimax normalized) Extraction: Principal components (Marked loadings } \\
Variable & Factor & Factor & Factor & Factor & Factor & Factor \\
& 1 & 2 & 3 & 4 & 5 & 6 \\
\hline Willingness & 0,247480 & 0,407177 & $-0,204138$ & 0,247481 & $-0,119360$ & 0,033054 \\
\hline Competence & $-0,055020$ & 0,681540 & 0,006961 & $-0,072000$ & 0,265825 & $-0,143970$ \\
\hline Tax collection & 0,208022 & 0,193628 & 0,113738 & 0,679960 & 0,040969 & 0,043309 \\
\hline $\begin{array}{l}\text { Collection } \\
\text { Tariffs }\end{array}$ & 0,132591 & 0,065282 & $-0,075041$ & $-0,362360$ & 0,549920 & $-0,087184$ \\
\hline Collection of levie & 0,681574 & $-0,003556$ & $-0,035835$ & $-0,123172$ & $-0,073222$ & $-0,030383$ \\
\hline $\begin{array}{l}\text { Administrative } \\
\text { difficulty }\end{array}$ & 0,059084 & $-0,045698$ & $-0,032242$ & $-0,025110$ & 0,030893 & 0,857102 \\
\hline Time saving & $-0,019193$ & 0,122648 & 0,774129 & 0,022727 & $-0,152556$ & $-0,235661$ \\
\hline Availability & 0,631722 & $-0,009950$ & 0,037099 & 0,165632 & 0,066763 & 0,065606 \\
\hline Electronisation & $-0,246514$ & 0,479615 & 0,041579 & $-0,040427$ & $-0,365937$ & 0,364061 \\
\hline Transaction costs & 0,164648 & 0,278856 & 0,194761 & $-0,570120$ & $-0,033999$ & 0,152900 \\
\hline Cost of postage & $-0,015977$ & 0,224791 & $-0,620793$ & 0,032046 & $-0,174028$ & $-0,250511$ \\
\hline Labor costs & $-0,152111$ & 0,061086 & 0,068049 & 0,266025 & 0,711466 & 0,122212 \\
\hline Expl.Var & 1,103872 & 1,051341 & 1,092940 & 1,102301 & 1,094582 & 1,060295 \\
\hline Prp.Totl & 0,091989 & 0,087612 & 0,091078 & 0,091858 & 0,091215 & 0,088358 \\
\hline
\end{tabular}

Source: Authors.

The analysis of the factor model itself is based on the analysis of factor loadings of the individual factors listed in Table 3. It is evident from the table that Factor 1 strongly correlates with the question of the collection of levies (0.68157) and availability (0.63172). Considering the above-mentioned fact and the plus sign of these significant correlations, the first common factor explaining the variability of respondents' replies can be attributed to the name "availability and effectiveness of levies collection". From the point of view of respondents' responses an increasing the efficiency of levies collection and improving the availability of contact points can contribute to increasing the efficiency of tax administration. 
The second factor strongly correlates with competence (0.68154) and is therefore called "competence of the tax office employees"; an increasing effectiveness of tax administration is achieved through increasing the competence of its employees. The third common factor strongly correlates with time savings (0.77413) and postage/shipping costs (0.62079). This factor can therefore be called "time savings". From the results it can be concluded that increasing the effectiveness of tax administration at this point can be achieved by reducing the time that taxpayers have to spend to meet their obligations and also by reducing the postage costs when sending reports. In the context of these conclusions, it seems necessary to electronize the entire tax system to address both of these issues. The fourth factor is highly correlated (0.67996) with tax collection. Thus, with the increasing efficiency of tax collection, it is possible - according to respondents' opinions - to increase the efficiency of the tax system. The fifth factor is correlated with the labour cost issue (0.71147). Thus, this significant factor can be classified as "labour costs". The last significant factor that affects the variability of respondents' answers correlates with the question of administrative difficulty of the tax and customs agenda $(0,8571)$ and therefore can be called "administrative difficulty".

On the basis of factor analysis, we can conclude that the 12 questions in the questionnaire that deal with the satisfaction of respondents with tax administration can be explained by the six common factors that stand in the background. These factors can be defined as follows:

- Factor 1: levies collection and availability,

- Factor 2: competence of tax administration employees,

- Factor 3: computerization of tax administration,

- Factor 4: effectiveness of tax collection,

- Factor 5: labour costs,

- Factor 6: administrative difficulty of tax administration.

Further analyses (Table 3) showed that the interdependence of Factor 1 (levies collection and availability) and Factor 4 (effectiveness of tax collection) creates only one factor-pure character that is dependent on the Factor 1, namely the "collection of levies". Although the "availability" is strongly correlated with Factor 1, we also observe a small dependence on Factor 4. Similarly, there is dependence of "tax collection" on Factor 4 but also dependence on Factor 1. In addition to these dependencies, the relationship of "transaction costs" and "collection of tariffs/customs" with tax collection effectiveness (Factor 4) can also be observed. In this case, however, a direct proportion is evident. In addition to the obvious dependencies (given in Table 3), the analysis of Factor 1 and Factor 5 (labour costs) also shows the dependence of "electronisation of tax administration" on labour costs; according to the respondents' opinion, electronisation is contributing to the reduction of labour costs. Interesting dependence can be seen between "collection of tariffs/customs" and labour costs as well as between "competence of tax administration staff" and labour costs. In this case, the respondents are of the opinion that increasing labour costs results in increased competence of tax administration staff as well as in higher efficiency of the customs collection. In addition to the above-mentioned facts, i.e. the strong dependence of "availability" and "collection of levies" on Factor 1 and "administrative difficulty" on Factor 6, we also see the dependence of "tax administration electronisation" on the Factor 6. According to the respondents' opinion, electronisation of tax administration will increase its administrative difficulty.

\section{Conclusion}

To ensure homogeneity we chose 1500 questionnaires to create a representative sample from the total number of completed questionnaires. Given the scale and difficulty of the survey, only partial results and findings are presented. In terms of research carried out, it can be said that there is a dissatisfaction with the overall tax and customs system in Slovakia, with the most critical point being the labour costs related to the tax and customs agenda as well as the costs of processing this agenda. At the same time, it points to the need to simplify the tax and customs system in the form of an agenda electronisation, the transparency of public finances and the general mistrust of the citizens against the tax evasion mechanism and the amount of money spent on tax and customs offices.

Based on the expected benefits of the tax reform mentioned in the document "Concept for the Reform of Tax and Customs Administration Reform, with a View to Unifying the Collection of Taxes, Customs Duties and Insurance Contributions" elaborated by the Ministry of Finance of the Slovak Republic, "unifying the collection of taxes, customs duties and insurance contributions into a single point will significantly reduce the administrative burden vis-a-vis the tax/contribution payers, will reduce bureaucracy and improve the perception of citizens or employers about mandatory payments", i.e. it is assumed that the gradual introduction will most likely to reduce the current dissatisfaction.

In addition to predetermined research objectives, the survey also revealed further weaknesses in the area of tax and customs administration, particularly in the area of citizens' education. From the total number of completed questionnaires, 447 respondents were aged 18-25, but only 291 questionnaires were relevant. This indicates low awareness of young 
people. Therefore, it is necessary to improve information and to "bring closer" the Slovak tax and customs administration system to students of secondary and higher education. Information campaign about the tax and customs reform in the Slovak Republic could partially improve this issue.

\section{References}

1. J. Dobrovič. Hodnotenie výkonnosti manažmentu efektívnej daňovej správy SR v kontexte regiónov pred reformou daňovej správy SR s návrhom jej zefektívnenia po reforme. Performance Evaluation of Effective Tax Administration Management of the Slovak Republic in the Regional Context before the Tax Administration Reform of the SR with a Proposal for Its Higher Effectivity after the Reform. Prešov: University of Prešov. (2015)

2. J. Belás, A. Chochol'áková, L. Gabcová. Satisfaction and loyalty of banking customers: a gender approach. Economics \& Sociology. 8(1), 176-188 (2015)

3. R. Rajnoha, D. Slivková, J. Dobrovič, Globatization and Transer Pricing in Multinational Corporations in Slovakia and OECD Countries - Analytical Study and Decision-Making Model on the Choice of Optimal Transfer - Pricing Method. Ekonomický časopis, 62(6), 609-630. (2014)

4. A. Korauš, J. Dobrovič, A. Ključnikov, M. Gombár, Consumer approach to bank payment card security and fraud. Journal of Security \& Sustainability Issues, 6(1), 85-102. (2016)

5. D. Tamulevičiené, Methodology of complex analysis of companies' profitability. Entrepreneurship and sustainability issues, 4(1), 53-63. (2016)

6. A. Korauš, R. Štefko, J. Dobrovič, Acqusition Activity in Financial Sector. 12th International Scientific Conference on European Financial Systems, Brno: Masarykova univerzita v Brne. (2015)

7. A. Ključnikov, J. Belás, L. Smrcka, The role of risk-taking and competitive aggressiveness in management of SMEs. Polish Journal of Management Studies, 14(1), 129-139. ISSN 2081-7452, (2016)7

8. J. Paulík, F. Kombo, A. Ključnikov. CSR as a driver of satisfaction and loyalty in commercial banks in the Czech Republic. Journal of International Studies. 8(3), 112-127 (2015)

9. A. Tvaronavičiené, G. Žemaitaitiené, T. Bilevičievé. Ecosystem for sustainable entrepreneurship: towards smart public procurement review procedures. Entrepreneurship and sustainability issues. 4(1), 39-52 (2016)

10. R. A. Musgrave, P. B. Musgrave. Public Finance in Theory and Practice. $5^{\text {th }}$ Ed. New Yok: McGraw-Hill Education. ISBN 0-07-044127-8 (2004)

11. J. H. Wu, Y. M. Wang. Measuring ERP success: The key-users' viewpoint of the ERP to produce a viable IS in the organization. Computers in Human behavior. 23(3), 1582-1596 (2007)

12. J. Belás, P. Bartoš, A. Ključnikov, J. Doležal. Risk perception differences between micro-, small and medium enterprises. Journal of International Studies. 8(3), 20-30 (2015)

13. Y. Bilan. Sustainable development of a company: Building of new level relationship with the consumers of XXI century. Amfiteatru Economic. 15, 687-701 (2013)

14. F. Chromjaková, R. Rajnoha. Economy of Innovation as a Part of the Increase of the Company Performance. Journal of Competitiveness. 1(1), 66-74 (2009)

15. A. Schultzová. Spolupráca členských štátov Európskej únie pri odhal'ovaní daňových podvodov. Ekonomický časopis. 53(3), 308- 313 (2005)

16. J. Belás, A. Chochol'áková, L. Gabčová. Bank Customers' Satisfaction, Customers' Loyalty and Additional Purchases of Banking Products and Services: A Case Study from the Czech Republic. Economics and Sociology. 8(3), 82-94 (2015)

17. A. Ključnikov, M. Sobeková Majková, A. Schwendemann, C. H. Knogler. Do SMEs in Slovakia face real difficulties in obtaining financing? Comparison of the studies from Slovakia and the EU. Journal of International Studies. 9(3), 36-52 (2016)

18. A. Zubal'ová. Daňové teórie. Bratislava: Vydavatel'stvo Ekonóm. ISBN 80-225-1789-5 (2003)

19. J. Belás, V. Demjan, Bank customers satisfaction: case studies from Czech Republic. Actual Problems of Economics, 12(162), 315-323 (2014)

20. J. Belás, G. Sopková. Significant determinants of the competitive environment for SMEs in the context of financial and credit risks. Journal of International Studies. 9(2), 139-149 (2016) 